\title{
Multi-level stakeholder engagement in flood risk management - A question of roles and power: Lessons from England
}

\author{
Thomas Thaler a,b, ${ }^{*}$, Meike Levin-Keitel \\ c a Flood Hazard Research Centre, Middlesex University, London, United Kingdom b Institute of Mountain Risk Engineering, University of Natural \\ Resources and Life Sciences, Vienna, Austria c Institute of Environmental Planning, Leibniz University Hanover, Hannover, Germany
}

\begin{abstract}
A b s t r a c t
In the past years, stakeholder engagement has become more important in flood risk management. On the one hand stakeholder engagement is often declared as a better way of management, a more successful way to reach consensus in policy discussions. On the other hand is the implementation of increasing stakeholder engagement far away from being as positive, where stakeholder engagement often ends in diverse difficulties and conflicts between political leaders and stakeholder groups. This paper aims to highlight participatory governance in flood risk management to provide an overview of the potential contributions and challenges of a participatory and collaborative governance approach. In this paper, we discuss the role of national authorities and local stakeholders in English flood risk management in three different examples (Bridgwater, Cockermouth and Morpeth). The results show that the Cockermouth and Morpeth flood risk management scheme is char-acterised by a high level of local self-responsibility in the planning and decisionmaking process. The study sites with high local capacity (Cockermouth and Morpeth) show a strong leadership at local level and bottom-up concepts and ideas. The local involvement in the discussion and decision-process depends on the local capacity (capacity to act), such as resources (knowledge, financial, time), interest, social and cultural capital. It strongly depends on these aspects, if localities are able to ensure their interests and needs at national level. \# 2015 Elsevier Ltd. All rights reserved.
\end{abstract}

Keywords: Stakeholder engagement Flood risk management Power Partnership funding Societal implications

\section{Introduction}

Stakeholder engagement is a core aspect of integrated flood risk management (Renn, 2008). Therefore, in recent years we have observed an increasing number of policy or academic papers in which stakeholder engagement has become more important in flood risk management (see this special issue). On the one hand, stakeholder engagement is often declared as a better way of management, a more successful way to reach consensus in policy discussions. On the other hand, the implementation of stakeholder engagement is far away from being as positive, where stakeholder engagement often ends in diverse difficulties and conflicts between political leaders and stakeholder groups with a much restricted outcome than expected (Menzel and Buchecker, 2013; O’Toole et al., 2013; Blackstock et al., 2014; Feliciano et al., 2014). Thus, the quite normative demand of a participatory and collaborative governance approach in the flood risk management debate has to be translated and transformed for everyday planning practice (Tseng and Penning-Rowsell, 2012; Blackstock et al., 2014; Newig et al., 2014). Scholars have defined stakeholder engagement as a social process working together to find a collective solution for a certain problem (Green and Penning-Rowsell, 2010). In the policy discussion, stakeholder engagement is often initiated by political parties/leaders (e.g. mayors) or by public admin- 
istration. Key arguments are to increase trust, legitimacy of local stakeholders in public administration (Krause and Dan Nielsen, 2014; Mees et al., 2014). In the literature, scholars often mentioned the inflexibility of public administration to reacting to the outcome of public participation processes (Haque et al., 2002; Speller, 2005; Reed, 2008; Tseng and Penning-Rowsell, 2012). Other problems are related to the lack of institutional support, about how to organise/deal with stakeholder engagement processes, to the lack of communi- cation, information sharing, especially to the lack of resources, particularly with respect to large participation processes (Thaler and Priest, 2014). Key problems lie in the different interests, views of each stakeholder group on flood risk management policy (Lupo Stanghellini and Collentine, 2008; Lupo Stanghellini, 2009; Reed et al., 2009; Levin-Keitel, 2014). Stakeholder engagement in general depends very much on the power relationship between the national, local level. Resulting out of the national authorities' roles, tasks, aspects of power can reach far behind these hierarchical/ heterarchical logics. This second aspect of stakeholder engagement focuses on the facets of who has power, who seems to be powerless, how different stakeholders deal with power (Lukes, 2005; Juntti et al., 2009; Thaler and Priest, 2014). Therefore, even if the national authority is in a very hierarchical and, so to speak, powerful position, local stakeholders are not necessarily in a powerless-victim position. First of all, the success of stakeholder engagement in flood risk management depends on the awareness of local stakeholders (administrative, citizens) that they can be involved. Thus, power includes the question of who the involved stakeholders are, including the not formal ones as well (Driessen et al., 2012; Levin-Keitel, 2014; Thaler and Priest, 2014). However, the local engagement strongly depends on their social capacity, such as knowledge, motivation/selfinterest, networks, organisation, procedural capacity (Kuhlicke et al., 2011). Therefore, social capacity strongly refers to the aspect of ability of stakeholders to ensure their interests (Kruse and Seidl, 2013). The presence and effectiveness of local grassroots organisations is a key aspect of sustainable collaborative governance in flood risk management.

* Corresponding author at: University of Natural Resources and Life Sciences, Peter-Jordan-Straße 82, 1190 Wien, Vienna, Austria. Tel.: +43 1476544364. Email address: thomas.thaler@boku.ac.at (T. Thaler). Available online at www.sciencedirect.com ScienceDirect journal homepage: www.elsevier.com/locate/envsci http://dx.doi.org/10.1016/j.envsci.2015.04.007 1462-9011/\# 2015 Elsevier Ltd. All rights reserved. The societal acceptance and capacity to engage in the policy and flood risk management planning process seems to be higher in the wealthy rural study sites than in Bridgwater. Most of the time the exclusion of private stakeholders as stakeholders in the partnership is based on a lack of political willingness to involve and to enforce private stakeholders to contribute. However, the influence of stakeholders in the flood risk management planning and decision-making practices depends on the local capacity as well as trust and openness in the public administration. Most of the different stakeholders have strong interdependent interests, such as economic growth vs. restriction in land use management or implementation of flood storages vs. structural engineering solutions, which cause conflicts between them. Further conflicts mainly arise due to funding; especially, the amounts of the individual contributions. This paper aims to discuss the role and the relationship between national and local stakeholders in the English flood risk management system. We highlight participatory governance in flood risk management to provide an overview of different implementation processes and the potential contributions and challenges of a participatory and collaborative governance approach in flood risk management. However, the paper does not stay in the simple description of the planning processes; rather the aim is to look further behind these examples, interpreting underlying key aspects of stakeholder engagement in flood risk management. Therefore, this paper deals with following two research questions:

(1) In how far characterises the relationship between national and local stakeholders the design and implementation of flood risk management strategies?

And (2) how the relationship between national and local stakeholders characterises the design and implementation of flood risk management strategies? 


\section{Conceptual framework}

To understand and to analyse the relationship between national and local stakeholders we developed a heuristicanalytical framework (Table 1); which is composed of a stepwise model including three main stages of interaction. The already mentioned key aspects - (1) the role of the national and local stakeholders on flood risk management policy, and (2) the power relationship between the national and local level in policy decision-making practices - are now explained in detail to outline the conceptual framework. 2.1. Stage 1 (hierarchical structure) Here, national authorities play the most crucial role in the partnership approach. A key aim for flood risk management, for example, is to develop and initiate project proposals for flood defence schemes (develop a project appraisal, ensure funding from national sources, organise all approval needs for the realisation of the project).

During this stage the national authorities are the project leaders, who also define the conditions with the stakeholders, e.g. cost sharing among the stakeholders. The focus is to find potential stakeholders (state and non-state stakeholders) and integrate them into the partnership approach. Building trust is important, especially between stakeholders who have never collaborated in the past. The overall tasks are to organise seminars and meetings, especially to communicate the potential hazards and risks, define problems, and find common objectives and measures. Furthermore, key tasks are to organise and ensure financial support from the national authorities. Since the national authorities are foreseen as the project leader and manager, their key requirements are managerial skills, they have the overall power in the planning and decision-making process. Often the local level does not seem to be in a very strong position in comparison to the national level, especially local grassroots organisations. 
Table 1 - Ideal relationships between national and local stakeholders in flood risk management.

\begin{tabular}{|c|c|c|c|}
\hline & Hierarchical structure (stage 1) & Heterarchical structure (stage 2) & $\begin{array}{l}\text { Responsible } \\
\text { autonomy (stage 3) }\end{array}$ \\
\hline National authority's role & $\begin{array}{l}\text { - Project initiator, leader and } \\
\text { manager and networker }\end{array}$ & $\begin{array}{l}\text { - Project manager and supporter } \\
\text { and relationship builder }\end{array}$ & $\begin{array}{l}\text { - Project supporter } \\
\text { and controller }\end{array}$ \\
\hline National authority's focus & $\begin{array}{l}\text { - Project leading } \\
\text { - Trust building } \\
\text { - Locate and integrated new stakeholders } \\
\text { in inter-local co-operation process }\end{array}$ & $\begin{array}{l}\text { - Project support } \\
\text { - Trust expansion }\end{array}$ & $\begin{array}{l}\text { - Trust exploitation } \\
\text { - Controlling }\end{array}$ \\
\hline $\begin{array}{l}\text { National authority's } \\
\text { competences }\end{array}$ & $\begin{array}{l}\text { - Communicator } \\
\text { - Technical expertise } \\
\text { - Networker } \\
\text { - Managerial skills }\end{array}$ & $\begin{array}{l}\text { - Analyser and problem solver } \\
\text { - Communicator } \\
\text { - Technical expertise } \\
\text { - Networker } \\
\text { - Managerial skills }\end{array}$ & $\begin{array}{l}\text { - Communicator } \\
\text { - Technical expertise }\end{array}$ \\
\hline National authority's task & $\begin{array}{l}\text { - Project planning and appraisal } \\
\text { - Project monitoring and controlling } \\
\text { - Funding Seminars and network events } \\
\text { - Branding }\end{array}$ & $\begin{array}{l}\text { - Project monitoring and controlling } \\
\text { - Funding } \\
\text { - Seminars and network events } \\
\text { - Branding }\end{array}$ & $\begin{array}{l}\text { - Project controlling } \\
\text { - Funding } \\
\text { - Seminars } \\
\text { - Branding }\end{array}$ \\
\hline
\end{tabular}

\subsection{Stage 2 (heterarchical structure)}

There is a shift of tasks and competencies from national authorities to the (local) stakeholders. The different tasks and competencies exist unranked next to each other (so to speak, parallel to a minor developed hierarchical structure). The key role of national authorities is to build and ensure the relationship between the stakeholders, especially to avoid a disintegration of the co-operation. An important aspect is the shift in relation to the aspect of trust (from trust building to trust expansion). Ingstrup and Damgaard (2013) defined this shift as an important growing phase in the inter-local cooperation (from actor bonds to social bonds and later to professional bonds). The role of the national authorities shifts from project initiator to project supporter. The shift in competencies refers mainly to aspects of soft skills, e.g. communicator or problem solver. Relating to tasks, the national authorities are focussed on the project monitoring and controlling instead of project planning at this stage. Implications for the local level are to profit from a shift in competencies and introduce themselves as an equal player, as either a local authority or grassroots organisation. 2.3. Stage 3 (responsible autonomy) Consists of an additional shift of tasks and duties from national authorities to the stakeholders of the co-operation. The national authorities devolves power and responsibility towards local stakeholders. In terms of flood risk management, this kind of relationship seems not to be realistic, because flood protection can be seen as a common good and, so to speak, one of the sovereign services of the state. Thus, even if one can identify a kind of semi-responsible autonomy of another actor (which means that the national authority transfers implementation rights), the national authority still occupies, for example, approval rights to influence and steer the policy implementation. However, the key focus of national authorities then can only be to project funding and controlling (financial and implementation).

\section{Methodology}

This study selected three study sites in England (Fig. 1) to analyse and to evaluate stakeholder engagement in English flood risk management policy. The paper uses study sites to provide an exploratory research approach (Yin, 1994) to understand and to evaluate the relationship between national and local stakeholders. The use of study sites allows this 
paper to investigate how flood risk management policy functions in practices, in particular to explore the consequences and impacts of the change in decision-making practices. The selection of study sites based on various criteria (matching, qualitative assessment and cross-case test) with the aim to generate and test research objectives and questions to provide new explanations. The selection processes include the choice of one or more study sites, where one independent variable as well as one dependent variable shows similarity (Gerring, 2006). All selected study sites are using partnership funding principle and are therefore relatively recent date and have a local focus. Table 2 summarises the main criteria for the selection of the study sites. The paper uses a qualitative research design-based on semi-structured interviews. In total 15 interviews were undertaken with a range of stakeholders from national and local level (list of interviews and communication with stakeholders are located in Appendix A). The selection process of the interviewees was based on a snowball sampling as well as from newspapers, academic journals and internet websites. Subsequent to Flick (1998), the process of data collection in every study site included three key steps: (1) recording semistructured interviews on the national and local level, with administrative bodies and civil grassroots organisations, including taking additional notes during and after the interview (pre- and post-scripts), (2) transcribing the recorded data, and (3) categorising the text. The semi-structured interviews (annex 1) were conducted face-to-face or by phone and transcribed in Microsoft Word Documents and, furthermore, coded and analysed using an Atlas.ti software package. For analysing the research results, we used a key-words-in- context method (Kramer and Revilla Diez, 2012) to analyse free-flowing texts with open-ended questions and to reduce the restriction from the 'research driver classification' (Ryan and Bernard, 2005).

\section{Study sites description}

The flood risk management system in England includes a wide range of different stakeholders on a national and local level. The Department of Environment, Food and Rural Affairs (Defra) and the Environment Agency (EA) as overall leaders in the definition of English flood risk management policy represent the national level. Defra defines the current policy direction and provides the funding scheme from the national government (policy responsibility). The EA leads the negotia- tion with third parties and provides the technical expertise in its role of owning the flood risk assets and being responsible for maintaining them (operational responsibility). In sum, these responsibilities underline the key roles of both organi-sations. The national stakeholders play an enormous role in flood risk management in England. Due to comprehensive rights (implementation rights, planning rights, approval rights, etc.) they can support stakeholder engagement, exclude specific stakeholders, determine the whole collabora- tive process and/or motivate local grassroots organisations. At the local level, the key stakeholders are the Lead Local Flood Authorities (LLFAs), Internal Drainage Boards, Water Industry, and Highway Road Authorities which are generally responsible for the ordinary water courses for pre-defined

\begin{tabular}{ll} 
Table $\mathbf{2}$ - Justification for the selection of the case studies. & \\
\hline Criteria & Justification \\
\hline $\begin{array}{l}\text { Type of flooding: different types of flooding (flash floods, fluvial } \\
\text { flooding, debris flow) }\end{array}$ & Mainly fluvial and pluvial flooding \\
Flood frequency and recent flood history & $\begin{array}{l}\text { Recent flood events: 2008 (Morpeth), 2009 (Cockermouth), 2014 } \\
\text { (Bridgwater) }\end{array}$ \\
Different socio-economic structures & Grassroots organisations vs. non-grassroots organisations \\
\hline
\end{tabular}





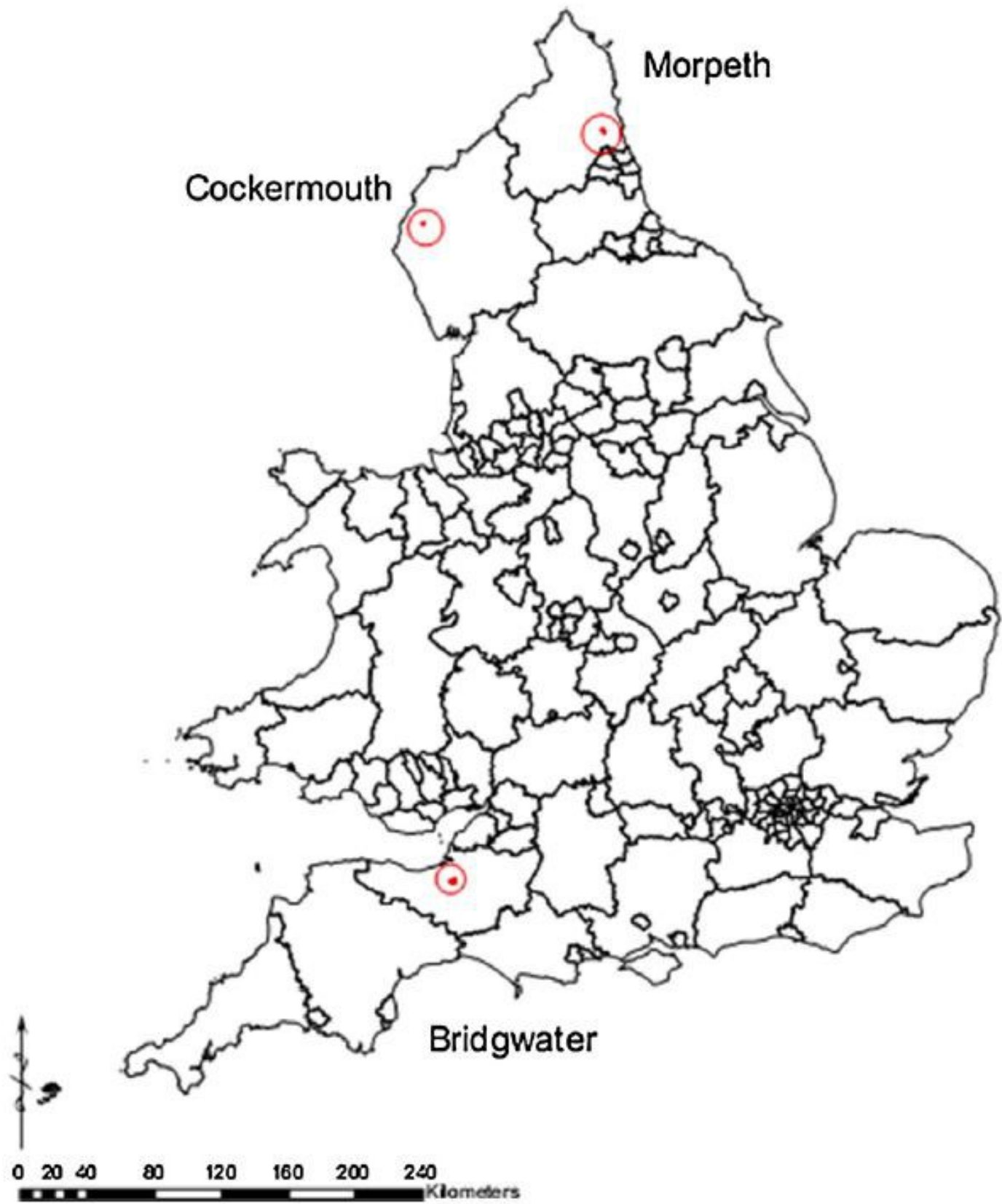

Fig. 1 - Selected study sites.

areas. However, the management of flooding shows little co-ordination and co-operation between the different operational actors. In urban areas, for example, the flood risk management system includes three main stakeholders: Water industry: responsible for water supply, sewage and treatment; Local authorities: responsible for road and gully drainage; and EA: responsible for main river management (Coulthard and Frostick, 2010). Consequences of the increase of stakeholders (in the past 40 years) in the management and governance of flood risk management are coordination and adjustment between different management systems. The LLFAs were introduced as recommendations of lessons learned from the summer floods of 2007 (Pitt, 2008). One of the key recommendations was to empower the local level to deal with local problems. The LLFAs are responsible for all sources of flooding from ordinary water courses, especially for the surface runoff and the groundwater flooding, but outside the Internal Drainage Boards areas. The LLFAs are responsible for the management of the risk of surface runoff, of groundwater and of ordinary water courses (UK Legislation, 2010). The selected study sites show different socio-economic characteristics (Table 3). The 
civil parish of Cockermouth is located in the highly frequented tourism area in the Lake District in the Borough of Allerdale. Cockermouth includes a large number of rural-oriented small and medium-sized enterprises (SMEs), with more than $80 \%$ of them affected by flooding in 2009. Implications were that SMEs heavily engage in the Cockermouth Flood Action Group (FAG) in the flood risk management debate. A similar situation can be found in Morpeth in Northumberland. The Morpeth study site includes a cooperative approach between three main stakeholders (Environmental Agency (EA), Northumberland County Coun-cil, Morpeth FAG). On the other hand, the study site of Bridgwater (Somerset) has been selected, with it being a contrasting example to Cockermouth and Morpeth: Bridgwater has no official local grassroots organisations and completely different socio-economic frameworks. Bridgwater is the largest study site with an area of $947 \mathrm{~km}$ and more than 35,000 citizens. Further, Bridgwater shows a higher indices of deprivation and lower level of education in compare to Cockermouth and Morpeth. Examining the stakeholder engagement in the policy decision process as well as flood risk management planning we can observe substantial differences between the study sites. In particular, Morpeth and Cockermouth are well endowed with the engagement of local stakeholders. In both study sites the local grassroots organisations show a high interest in the development and realisation of a new flood alleviation scheme for its community. For example, the Cockermouth FAG organised external funding of $£ 400,000$ to close the funding gap. In the case of Morpeth the FAG plays a dominant role in the discussion because of its network and interactions with different public authorities (locally and nationally). The formation of the FAG is often based on recent flood histories, especially as a reaction of frustration in welleducated and wealthy areas. 'Being heard' is a central problem in flood risk management, where actors at the local level have the feeling of not being heard by policymakers.

\section{Role of local stakeholders in the design of national flood risk management strategies}

Overall, the Cockermouth and Morpeth flood risk management schemes is characterised by a high level of local decision- making process. In particular, in the management and initiation of local solutions referring to flood risk management strategies. Local stakeholders show high interest, knowledge and resources in developing of flood defence schemes in their town, particularly if local key stakeholders are proceeding through local FAGs. In recent years they changed their relationship and co-operation with the EA - from a lobby group towards an equal partner, changing essentially the partnership agreement. However, the EA is still a key player in the discussion, e.g. in the negotiation with different stakeholders, like the Cumbria County Council. The result was a common negotiation and conversation about, particularly, flood allevia- tion schemes in towns between the EA and local stakeholders. In the planning process, concerned local stakeholders were strongly involved in the design of the flood defence scheme. A central impact was the change of the national authorities from promoting, networking and leading towards more of a project manager, analyser and problem solver. The empirical results show a strong disconnection between leaderships of national authorities and the capacity of local stakeholders. The study sites with a high local capacity (Cockermouth and Morpeth) show strong leadership at local level and bottom-up concepts and ideas. The local involvement in the discussion and decision process depends on the local capacity (capacity to act), such as resources (knowledge, finance, time), interest, and social and cultural capital (Thaler and Priest, 2014). It strongly depends on whether localities are able to represent their interest and needs at national level. In general, encouragement of local engagements in the policy discussion and decision process requires 'space of engagement'. The empirical results show different ranges of local involvement (see Fig. 2), strongly depending on the study sites, although the national level has mostly a central role in the flood risk management system. 
Table 3 - Comparison of socio-economic characteristic in three study sites; adapted from March 2011 census data.

\begin{tabular}{lccc} 
Characteristic & Cockermouth & Morpeth & Bridgwater \\
\hline Area $(\mathrm{km})$ & 217 & 360 & 947 \\
Population & 8761 & 14,017 & 35,886 \\
Economically active; total in \% & 70.58 & 65.32 & 71.71 \\
Education (\% aged 16 and over with no qualifications) & 20.66 & 20.25 & 29.64 \\
Household is not deprived in any dimension (\%) & 48.98 & 49.60 & 36.05 \\
\hline Source: ONS (2013). & & & \\
\hline
\end{tabular}

In England the focus of the national level is on funding and the whole planning process, including future maintenance.

One of the three study sites is characterised by this powerful role of the national authority (stage 1) defining and implementing the local flood risk management scheme (Bridgwater). However, the interviews of Morpeth have shown a power distribution manoeuvre from public authorities towards local elite groups. Despite this new co-operation approach the EA shifted away from being the engineer (designing and building flood defence schemes) towards more project management tasks. Above all, the consequences for the EA were a stronger focus on communication with (local) stakeholders as well as a stronger focus on project manage- ment tasks, such as budgeting and administrating the contribution of the different stakeholders (shift from stage 1 to 2). In line with Jackson (2001) and Clifford (2013), partnership funding needs a different organisational culture, skills, knowledge and competencies. The interview data for the Morpeth study site showed a shift of the relationships, activities and self-realisations among the different agents. First, the 2008 flood event and its consequences, e.g. insurance problems, increased the interest of the local stakeholders. They created the Morpeth FAG shortly after the flood event. Second, the partnership funding scheme opened the door towards the local authorities. The stakeholders were partly involved in the planning and decision process of the flood defence scheme to reduce the risk of future flood events from main rivers. Nevertheless, the different stakeholders (Northumberland County Council and FAG) played a minor role in the design and planning process in Morpeth. The main reasons for this were that the businesses' case and proposal of the defence scheme were already designed under the 'old' scheme. The key driver for the local stakeholders to get involved was to satisfy the requirements from the insurance industry. Flood insurance plays a central role in the English flood risk management system (Lammond et al., 2009) — not only in terms of compensation. A central policy is the need for insurance cover, whereby obtaining a mortgage, and therefore has implications for selling the property (Interview 9). Furthermore, an important aspect was the high level of knowledge and expertise - social capacity (Kuhlicke et al., 2011; Thaler and Priest, 2014) - by the local stakeholders: e.g. Northumberland County Council has four engineers in their team (Interview 15). However, their influence in the planning process was mainly concentrated upon the re-design of the flood storage scheme, especially for the change of the locations (Interviews 10, 14, and 15). On the other hand, in the Bridgwater partnership funding scheme, Sedgemoor County Council and the EA are the key stakeholders in the overall discussion, planning and management. Similar to the other two study sites, the town council played a minor role in the ongoing debate in Bridgwater. The town council showed a passive role in the planning, management and implementation process. A key reason is the lack of local capacity to engage in the decision-making practices, such as a local FAG. One explanation for the absence of a local FAG is the lack of recent flood events in the town, which generally influence the risk perception and the interest in flooding (Kuhlicke et al., 2011). Another interpretation is that the creation of local grassroots organisations, such as FAG, also needs socio-economic structures, e.g. cultural capital, income and interest. In addition, Bridgwater shows a different socioeconomic situation to the other two study sites. First, the town shows a much higher level of deprivation than Morpeth or Cockermouth. Second, the level of knowledge, experiences, wealth and contacts to different government organisations is widely different. Morpeth and Cockermouth show a wide network with different policymakers from different govern- mental levels. Furthermore, both 
towns show a large number of well-educated, middle-class citizens. These aspects are less present in Bridgwater with the result of a very low involvement of the local stakeholders in the discussion. The relationship between Bridgwater and the EA is characterised by a relatively low local engagement and management by the community to take over tasks and responsibility from the EA. The EA strongly leads the overall discussion, such as the design of contribution (Interviews 10 and 11).

\section{National \\ leadership}

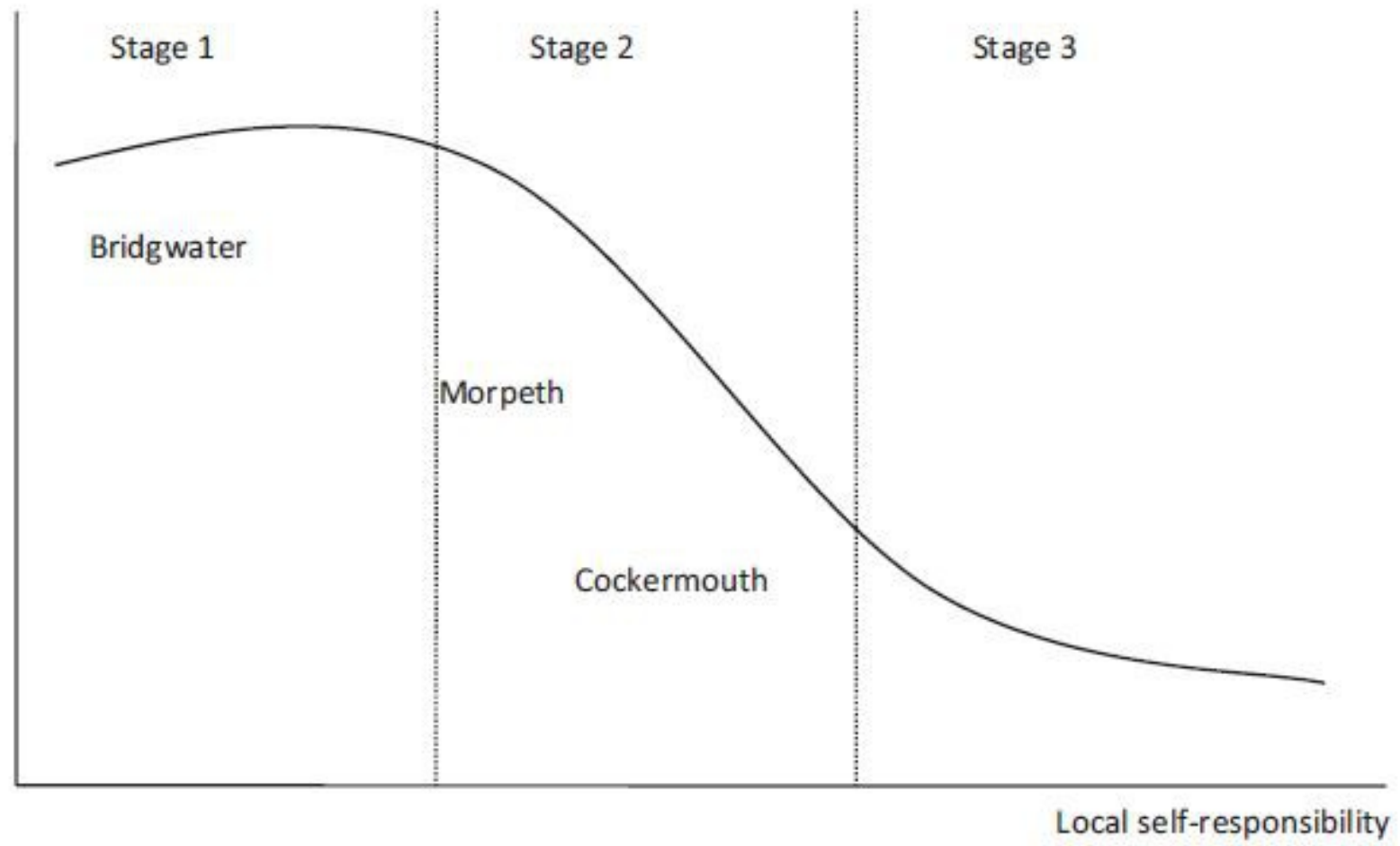

\section{Fig. 2 - Role of national authorities and local stakeholders in English flood risk management policy.}

\section{Power relationship between national and (local) stakeholders}

The aspect of power is, in general, a substantial term in the network structure (Allen, 2009). Overall, local stakeholders are strongly dependent on the national authorities. Nevertheless, the possession of power depends on the position of the actor in the interaction with others (Sayre, 2005; Bues and Theesfeld, 2012; Cox, 2013). In particular, in the study sites we identified a strong dependence relationship between the different stake-holders in terms of power and resources (Table 4). 


\begin{tabular}{|c|c|c|c|c|c|}
\hline \multirow{2}{*}{\multicolumn{2}{|c|}{ Dependence relationship }} & \multirow[t]{2}{*}{ Consequences on bargaining process } & \multicolumn{3}{|c|}{ English study sites } \\
\hline & & & Cockermouth & Morpeth & Bridgwater \\
\hline \multicolumn{2}{|c|}{ Depending on government support Potential power } & Relative bargaining power & + & + & -- \\
\hline \multirow{5}{*}{ Education and knowledge } & Network power & Relative bargaining power & ++ & ++ & -- \\
\hline & Sanction power & Distributional consequences & + & + & -- \\
\hline & Access to information & Distributional consequences & ++ & ++ & -- \\
\hline & Knowledge & Distributional consequences & ++ & ++ & -- \\
\hline & Cultural capacity & Distributional consequences & ++ & ++ & -- \\
\hline
\end{tabular}

Of course, the dependency on natural resources has a key role in the flood risk management discussion. However, the empirical results show that 'community support groups' - like FAG - include a substantial role in the engagement process of local stakeholders as well. Therefore, we distinguished between middle-class and working-class communities. In general, we noticed a greater lack of local community support groups in working-class communities. They are more focussed on wealthy rural middle-class communities (Interview 5). The consequences are that local authorities as well as local stakeholders are less involved in the management process. Consequently, local authorities with local support groups show a privileged position. The consequences are that communities without local support groups tend to move the responsibility and the involvement towards County Council level, e.g. the cases of Bridgwater. In Bridgwater the key stakeholders were the County Councils (Sedgemoor for Bridgwater) in the negotiation process (Interviews 12 and 13). In the Cockermouth study site, we observed a strong bottom-up management system. This was in contrast to the other study sites, where the national authorities provide the flood risk management plans - top-down management system. However, the two FAG communities show a high degree of interest, experience and knowledge in the ongoing policy discussion, especially the Cockermouth study site. In sum, the role of the national authority (in England the Environ- mental Agency (EA)) is the key actor in the flood risk management discussion, and in conclusion in its stakeholder engagement. In recent years the EA have changed their policy discussion. The previous EA approach foresaw a strong top- down approach in the decision process with no or minor engagement by local agents (Interview 3). The main reason was the fear of losing power with the consequences of no pro-active relationship and engagement with the local stakeholders. However, the new policy direction changed the position not only on a local but also on a national level. The engagement of local stakeholders enforced national authorities to co-operate with (local) stakeholders (Inter- views 7, 8, and 9).

Participant: Under the old system we'd get 100\% funding so we'd do a project appraisal and develop a business case and we would decide what the best solution was and, yes, we'd talk to the residents but most of the time we're kind of saying this is what we think is the right solution for your community, and they'd agree or disagree and sometimes, if they disagreed, we'd go ahead if we thought it was the right thing to do, but we'd try to get their buy in to it and we'd deliver that scheme. Now because we can only fund so much, and some projects do get $100 \%$ funding from us, but especially when they don't and partnership funding really kicks in, we need to do a lot of work around obviously getting the extra funding in, a lot of working much more closely with those partners, because if they're putting the money in they have a right to say what comes out of it, and also the outcome can be different. So the outcome can be much less or much more because they have to put more or less in (National Authority, England).

This quote, indicated under the previous system, exem-plifies how the EA focussed their work with the community mainly to show them their best solutions - strongly the top-down management system. The EA plays the central role in flood risk management policy. The organisation is the key actor in the policy discussion and definition. The main 
reasons for this are their technical knowledge, their central role in funding, and their permission power. Overall the (local) stakeholders strategically depend on the national authorities. The national authorities are leading the design and develop- ment of flood alleviation schemes. However, their role strongly depends on the input from local stakeholders and others, as seen in Cockermouth. The further issue refers to education and knowledge characteristics. Both features play an important role in the interaction with national authorities. Moreover, other scho-lars underlined the importance of knowledge and education or the social capacity to interact and to ensure their interests (Bues and Theesfeld, 2012; Kuhlicke et al., 2011). Good knowledge and cultural and social capitals have been a key point in the interaction with the national authorities. This has been shown in several empirical results.

Participant: They were quite intelligent people, profes-sionals in their own right with different skill sets, and I had a meeting with them and they presented to me a cost proposal for constructing an overflow channel to take out a meander just downstream of the town and reduce flows that way, and it was quite professionally put together (. .) there was a bit of a turning point that came about and rather than being a sort of lobbying group they almost became ... well they did become stakeholders of the project team, and we ran an appraisal and produced a business case (National Authority, England).

The study sites with community support groups, such as FAG, show a higher interest and knowledge in the ongoing flood risk management discussion. This shows their interaction and network with the national government and its bodies. Similar results have been found in education and knowledge characteristics, which play a key role in the social structure in flood risk management discussion. Subsequently, communities with local grassroots organisations tend to co-decide the local flood risk management plan, which is a key issue in partnership funding policy. The outcome will be that some local authorities are able to engage local stakeholders to get involved in the flood risk management process and to ensure their interests. The involvement of local stakeholders includes also the capacity and power to change the local flood risk management schemes, e.g. in Cockermouth. Similar developments and problems were identified with the new spatial and land use management planning policy in England (see also Haughton et al., 2013).

\section{Discussion and conclusion}

The interviews revealed that the local level is seen as a decisive factor in the English flood risk management system. The new direction within the EA devolves power and responsibility towards local stakeholders, such as grassroots organisations like FAG, which need adequate structures and resources to use this empowerment (social capacity). The outcome is the increased competition between the different local communities and a consequent shift to exclusive flood risk management policies. The objective is to realise flood alleviation schemes in the areas, where anybody can pay and/or lobby for them. An interesting observation from these interviews is that the actual policy in flood risk management allows place-specific arrangements in the design and level of standard protection, positively for localities with an adequate financial and cultural background; there are also negative consequences for communities without an adequate social and cultural background (lack of interaction at political level) or financial background (not necessarily financial resources to realise higher flood protection standards). Additionally, the final decision has shifted from a technical-objective towards a more political-subjective approach. Key objectives were the economic viabilities of the places which are stabilising norms and values in partnership development as well as ensuring a political engagement by local stake- holders and others: re-generation for Bridgwater, and affordability insurance payments, especially, for Cocker- mouth and Morpeth. In sum, the English policy opens a wide range of possibilities and different approaches, 
which strongly depend on local stakeholders and their interests and social capacity. Therefore, the local stakeholders have more responsibility and space than those in the 'old' political system. The new funding policy provides these new opportunities for local stakeholders, but this requests also the mobilisation of local stakeholders (Cox, 1998). The FAGs have built a relationship with national stakeholders and used the space of engagement to influence the policy discourse on a national level (Cox, 1998; Kythreotis and Jonas, 2012). Interestingly, in terms of power, the local groups influenced particularly the first and second dimensions of the power relationship (Lukes, 2005). The local grassroots organisations, such as Cockermouth and Morpeth FAG, modified the behaviour of the national authorities, such as the EA, or other local stakeholders, such as the County Council, within the decision-making process, mainly concerning the change of the design of flood alleviation schemes (first dimension). Furthermore, the local groups had the ability to shape the whole policy agenda. In the Morpeth study, for example, the interaction with local grassroots organisations modified the policy framework for the County Council to close the funding gap in Morpeth and to avoid additional fully funded projects within the county (second dimension). Here the FAG controlled the agenda of the County Council. The conse- quences of these new policy re-arrangements were new governance arrangements, policy outcomes and power relationships between different levels initiated by public and private stakeholders and others (Jordan, 2008). In sum, the policy problem is locally oriented, but where the FAG utilised political networks to ensure their needs and inter- ests. The FAG has been a powerful vehicle for the mobilisa- tion at local level, as observed in Cockermouth and Morpeth and found during the interviews. At national level the FAG interact with national politicians (i.e. Members of Parliament), especially in the cases of Cockermouth and Morpeth. The empirical results show that not everyone from the local level is able to jump to a higher level. However, an important issue refers to the adequate background of the local stakeholders at national level to change the social interac- tions and power structures, such as local grassroots organisations in the study sites of Cockermouth and Morpeth. The new policy direction includes a stronger position towards local stakeholders in the decision-making process. However, the actual political strategy in flood risk management were strongly followed by the marginalisation of stakeholders. Subsequently, the local stakeholders demand to influence the current local flood risk management discussion. This explains the strong presence of rural local stakeholders in the new policy discussion. However, the analysis of the inter- views revealed that only a few local stakeholders have the capability to use this opportunity. The consequences were that the FAG created 'parallel' networks to interact at national level (Allmendinger and Haughton, 2009).

\section{Acknowledgments}

The research leading to these results has received funding from the JPI-Climate project TRANS-ADAPT funded by the Austrian Federal Ministry of Science, Research and Economy (BMWFW), the French National Research Agency (ANR), the Ireland Environmental Protection Agency (EPA) and the Netherlands Organisation for Scientific Research (NWO) and Middlesex University, London. Furthermore, the authors would like to thank the two anonymous reviewers for their valuable comments and suggestions to an earlier version of this paper.

\section{Appendix A. Supplementary data}

Supplementary data associated with this article can be found, in the online version, at http://dx.doi.org/10.1016/j. envsci.2015.04.007. 


\section{Ref e r e n e s}

Allen, J., 2009. Three spaces of power: territory, networks, plus a topological twist in the tale of domination and authority. J. Power 2 (2) 197-212, http://dx.doi.org/10.1080/ 17540290903064267.

Allmendinger, P., Haughton, G., 2009. Soft spaces, fuzzy boundaries, and metagovernance: the new spatial planning in the Thames Gateway. Environ. Plann. A 41 (3) 617-633, http://dx.doi.org/10.1068/a40208.

Blackstock, K., Dinnie, L., Dilley, R., Marshall, K., Dunglinson, J., Trench, H., Harper, K., Finan, K., MacPherson, J., Johnston, E., Griffin, A., 2014. Participatory research to influence participatory governance: managing relationships with planners. Area, http://dx.doi.org/10.1111/area.12129.

Bues, A., Theesfeld, I., 2012. Water grabbing and the role of power: shifting water governance in the light of agricultural foreign direct investment. Water Altern. 5 (2) 266-283.

Clifford, B.P., 2013. Reform on the frontline: reflections on implementing spatial planning in England, 2004-2008. Plan. Pract. Res. 28, 361-383, http://dx.doi.org/10.1080/ 02697459.2012.725550.

Coulthard, T.J., Frostick, L.E., 2010. The Hull floods of 2007: implications for the governance and management of urban drainage systems. J. Flood Risk Manage. 3 (3) 223-231, http:// dx.doi.org/10.1111/j.1753-318X.2010.01072.x.

Cox, K.R., 1998. Spaces of dependence, spaces of engagement and the politics of scale, or: looking for local politics. Polit. Geogr. 17 (1) 1-23, http://dx.doi.org/10.1016/S0962- 6298(97)00048-6. Cox, K.R., 2013.

Territory, scale, and why capitalism matters. Territory Polit. Governance 1 (1) 46-61, http://dx.doi.org/ $10.1080 / 21622671.2013 .763734$.

Driessen, P.P.J., Dieperink, C., van Laerhoven, F., Runhaar, H.A.C., Vermeulen, W.J.V., 2012. Towards a conceptual framework for the study of shifts in modes of environmental governance-experiences from The Netherlands. Environ. Policy Governance 22 (3) 143-160, http://dx.doi.org/10.1002/ eet.1580.

Feliciano, D., Hunter, C., Slee, B., Smith, P., 2014. Climate change mitigation options in the rural land use sector: stakeholders' perspectives on barriers, enablers and the role of policy in North East Scotland. Environ. Sci. Policy 44, 26-38, http:// dx.doi.org/10.1016/j.envsci.2014.07.010.

Flick, U., 1998. An Introduction to Qualitative Research. Sage Publication Ltd, London. Gerring, J., 2006. Case Study Research. Principles and Practices. Cambridge University Press, Cambridge. Green, C., Penning-Rowsell, E., 2010. Stakeholder engagement in flood risk management. In: Pender, G., Faulkner, H. (Eds.), Flood Risk Science and Management. Wiley-Blackwell, West Sussex, pp. 372-385. 
Haque, C.E., Kolba, M., Morton, P., Quinn, N.P., 2002. Public participation in the Red River Basin management decisions and preparedness for the next flood. Environ. Hazard. 4 (4) 87-104,

http://dx.doi.org/10.1016/j.hazards.2003.10.001.

Haughton, G., Allmendinger, P., Oosterlynck, S., 2013. Spaces of neoliberal experimentation: soft spaces, postpolitics and neoliberal governmentality. Environ. Plann. A 45 (1) 217-234, http://dx.doi.org/10.1068/a45121.

Ingstrup, M.B., Damgaard, T., 2013. Cluster facilitation from a cluster life cycle perspective. Eur. Plann. Stud. 21 (4) 556-574, http://dx.doi.org/10.1080/09654313.2012.722953. Jackson, P.M., 2001. Public sector added value: can bureaucracy deliver? Public Adm. 79, 5-28, http://dx.doi.org/10.1111/

Jackson, P.M., 2001. Public sector added value: can bureaucracy deliver? Public Adm. 79, 5-28, http://dx.doi.org/10.1111/ 1467-9299.00243.

Jordan, A., 2008. The governance of sustainable development: taking stock and looking forwards. Environ. Plann. C: Gov. Policy 26 (1) 17-33, http://dx.doi.org/10.1068/cav6.

Juntti, M., Russel, D., Turnpenny, J., 2009. Evidence, politics and power in public policy for the environment. Environ. Sci. Policy 12 (3) 207-215, http://dx.doi.org/10.1016/ j.envsci.2008.12.007.

Kramer, J.P., Revilla Diez, J., 2012. Catching the local buzz by embedding? Empirical insights on the regional embeddedness of multinational enterprises in Germany and the UK. Reg. Stud. 46 (10) 1303-1317, http://dx.doi.org/ 10.1080/00343404.2011.571240.

Krause, T., Dan Nielsen, T., 2014. The legitimacy of incentive-based conservation and a critical account of social safeguards. Environ. Policy Sci. 41, 44-51, http://dx.doi.org/ 10.1016/j.envsci.2014.04.015.

Kuhlicke, C., Steinfuehrer, A., Begg, C., Bianchizza, C., Bruendl, M., Buchecker, M., De Marchi, B., Di Masso Tarditti, M., Hoeppner, C., Komac, B., Lemkow, L., Luther, J., McCarthy, S.S., Pellizzoni, L., Renn, O., Scolobig, A., Supramaniam, M., Tapsell, S., Wachinger, G., Walker, G., Whittle, R., Zorn, M., Faulkner, H., 2011. Perspectives on social capacity building for natural hazards: outlining an emerging field of research and practice in Europe. Environ. Sci. Policy 14 (7) 804-814, http://dx.doi.org/10.1016/j.envsci.2011.05.001.

Kruse, S., Seidl, L., 2013. Social capacity for drought risk management in Switzerland. Nat. Hazard. Earth Syst. Sci. 13 (12) 3429-3441, http://dx.doi.org/10.5194/nhess-13-3429- 2013. Kythreotis, A.P., Jonas, A.E.G., 2012. Scaling sustainable development? How voluntary groups negotiate spaces of sustainability governance in the United Kingdom. Environ. Space D: Soc. Space 30 (3) 381-399, http://dx.doi.org/10.1068/ d11810.

Lammond, J.E., Proverbs, D.G., Hammond, F.N., 2009. Accessibility of flood risk insurance in UK: confusion, competition and complacency. J. Risk Res. 12 (6) 825-841, http://dx.doi.org/10.1080/13669870902768614. 
Levin-Keitel, M., 2014. Managing urban riverscapes: towards a cultural perspective of land and water governance. Water Int. 39 (6) 842-857, http://dx.doi.org/10.1080/ 02508060.2014.957797.

Lukes, S., 2005. Power. A Radical View, second ed. Palgrave Macmillan, London. Lupo Stanghellini, P.S., 2009. Stakeholder involvement in water management: the role of the stakeholder analysis within participatory processes. Water Policy 12 (5) 675-694, http:// dx.doi.org/10.2166/wp.2010.004.

Lupo Stanghellini, P.S., Collentine, D., 2008. Stakeholder discourse and water management—implementation of the participatory model CATCH in a Northern Italian alpine sub-catchment. Hydrol. Earth Syst. Sci. 12 (2) 317-331.

Mees, H.L.P., Driessen, P.P.J., Runhaar, H.A.C., 2014. Legitimate adaptive flood risk governance beyond the dikes: the case of Hamburg, Helsinki and Rotterdam. Reg. Environ. Change 14 (2) 671-682, http://dx.doi.org/10.1007/s10113013-0527-2.

Menzel, S., Buchecker, M., 2013. Does participatory planning foster the transformation toward more adaptive socialecological systems? Ecol. Soc. 18 (1) 13, http://dx.doi.org/ 10.5751/ES-05154-180113.

Newig, J., Challies, E., Jager, N.W., Kochska“mper, E., 2014. What role for public participation in implementing the EU Floods Directive? A comparison with the Water Framework Directive, early evidence from Germany, and a research agenda. Environ. Policy Governance 24 (4) 275-288, http:// dx.doi.org/10.1002/eet.1650.

O’Toole, K., Keneley, M., Coffey, B., 2013. The participatory logic of coastal management under the project state: insights from the Estuary Entrance Management Support System (EEMSS) in Victoria, Australia. Environ. Sci. Policy 27, 206- 214, http://dx.doi.org/10.1016/j.envsci.2012.12.011. ONS, 2013. ONS 2011 Census Data. Office for National Statistics, Newport.

Pitt, M., 2008. The Pitt Review: Learning Lessons from the 2007 Floods. Cabinet Office, London. Reed, M.S., 2008. Stakeholder participation for environmental management: a literature review. Biol. Conserv. 141 (10) 2417-2431, http://dx.doi.org/10.1016/j.biocon.2008.07.014. Reed, M.S., Graves, A., Dandy, N., Posthumus, H., Hubacek, K., Morris, J., Prell, C., Quinn, C.H., Stringer, L.C., 2009. Who's in and why? A typology of stakeholder analysis methods for natural resource management. J. Environ. Manage. 90 (5) 1933-1949, http://dx.doi.org/10.1016/j.jenvman.2009.01.001.

Renn, O., 2008. Risk Governance Coping with Uncertainty in a Complex World. The Earthscan Risk in Society Series, Taylor and Francis Group, London. Ryan, G.W., Bernard, R., 2005. Data management and analysis methods. In: Denzin, N.K., Lincoln, Y. (Eds.), Handbook of Qualitative Research. second ed. Sage, London, pp. 769-802.

Sayre, N.F., 2005. Ecological and geographical scale: parallels and potential for integration. Prog. Hum. Geogr. 29, 276-290, http://dx.doi.org/10.1191/0309132505ph546oa.

Speller, G., 2005. Improving community and citizen engagement in flood risk management decision making, delivery and flood response. In: Environment Agency Science Technical Report SC040033/SR3. Environment Agency, Bristol. 
Thaler, T.A., Priest, S.J., 2014. Partnership funding in flood risk management: new localism debate and policy in England. Area, http://dx.doi.org/10.1111/area.12135.

Tseng, C.P., Penning-Rowsell, E., 2012. Micro-political and related barriers to stakeholder engagement in flood risk management. Geogr. J. 178 (3) 253-269, http://dx.doi.org/ 10.1111/j.1475-4959.2012.00464.x. UK Legislation, 2010. Flood and Water Management Act 2010. UK Parliament, London, Chapter 29. Yin, R.C., 1994. Case Study Research: Design and Methods (Applied Social Research Methods), second ed. Sage, London. 